\title{
O znaczeniu przedmiotowym i metatekstowym jednostek regularny i regularnie
}

Słowa klucze: semantyka leksykalna, składnia, przymiotnik, przysłówek, operator metapredykatywny

1. Przedmiotem rozważań w niniejszym artykule jest status językowy ciągów regularny i regularnie. Spróbuję odpowiedzieć na pytanie, w jaki sposób funkcjonują one w tekstach, na jakich poziomach języka operują, jaka jest kwalifikacja gramatyczna obydwu ciągów. Próba rekonstrukcji znaczenia tych wyrażeń zostanie przedstawiona na tle jednostek, które w słownikach języka polskiego zostały uznane za wyrażenia bliskie im znaczeniowo lub z nimi synonimiczne (por. ISJP). Mowa tu mianowicie o jednostkach równomiernie, miarowo, a także za każdym razem.

1.1. Podejmując się rekonstrukcji znaczenia dowolnej jednostki języka, należy postawić przede wszystkim pytanie o jej kwalifikację gramatyczną, a wcześniej o poziom języka, do którego dana jednostka należy. Wyrażenia językowe mogą funkcjonować na poziomie przedmiotowym lub organizować wypowiedzenie na poziomie meta. Zgodnie z ustaleniami J. Wajszczuk (2005) jednostki z poziomu przedmiotowego wchodzą w zwykłe związki syntaktyczne $\mathrm{z}$ innymi wyrażeniami w wypowiedzeniu, funkcja jednostek z poziomu meta jest zgoła inna. Stanowią one rodzaj komentarza jednostek z przedmiotowego poziomu języka. Do klasy tej należą zarówno wyrażenia 
metapredykatywne (np. prawie, niespetna), jak i wyrażenia metatekstowe. Te drugie są komentarzami do całego wypowiedzenia. Charakterystyczne jest dla nich podwójne odniesienie: do samej wypowiedzi i do nadawcy tej wypowiedzi (Grochowski 2007, 2008b).

Niektóre jednostki o znaczeniu przedmiotowym mają swoje homonimiczne odpowiedniki w klasie wyrażeń metatekstowych. Słowniki języka polskiego bardzo rzadko notują ten fakt.

1.2. Wyrażenia regularny i regularnie we wszystkich podstawowych słownikach języka polskiego (SJPD, SJPSz, SWJP, ISJP, USJP) opisywane są jako jednostki polisemiczne. Żaden ze słowników nie zauważa natomiast faktu istnienia homonimicznych z nimi jednostek należących do metatekstowego poziomu języka. Przykłady użyć, w których pojawia się operator metatekstowy, stanowią egzemplifikację jednego ze znaczeń przedmiotowych jednostki, np. Widzisz pan, on to jest wariat regularny, taki, co to o nim ludzie mówiq (ISJP). Wbrew opisom słownikowym, należałoby tymczasem wyróżnić dwie jednostki o kształcie REGULARNY (regularnyl - przymiotnik i regularny2 - operator metatekstowy) oraz dwa leksemy o postaci REGULARNIE (regularnie1 - przysłówek i regularnie2 - operator metatekstowy). Homonimii gramatycznej przymiotnika, przysłówka i operatorów metatekstowych towarzyszy opozycja semantyczna członów odpowiednich par jednostek. Oto przykłady wypowiedzeń1, w których występują badane wyrażenia:

(1) Regularny masaż przy użyciu olejku da spektakularne efekty.

(2) Jeśli twój okres jest regularny, będziesz znała swój cykl.

(3) Nie wolno zapominać o regularnym podlewaniu kwiatów.

(4) Czasopismo musi się ukazywać regularnie.

(5) Z początku zapiski w pamiętniku pojawiały się codziennie, z czasem zaczął notować mniej regularnie.

(6) Wszystkie rośliny są troskliwie pielęgnowane i większość regularnie zakwita.

(7) Nie prosił o kawę, i bardzo dobrze, regularna lura!

1 Do przedstawionych analiz wykorzystany został materiał źródłowy pochodzący z korpusu PWN, a także materiał zawarty w słownikach ogólnych współczesnego języka polskiego. Część wypowiedzeń egzemplifikujących stawiane hipotezy to przykłady własne, skonstruowane na zasadzie analogii do oryginalnych wypowiedzeń pochodzących z korpusu. 
(8) Widzisz pan, on to jest wariat regularny!

(9) Dostała regularne lanie.

(10) To regularne kłamstwo!

(11) On regularnie skłamał.

W kontekstach (1)-(6) jest użyty przymiotnik regularnyl lub przysłówek regularnie o odniesieniu wyłącznie przedmiotowym. Wypowiedzenia (7)-(11) są przykładami użycia metaoperatora. Wyrażenia regularny i regularnie mają w nich odniesienie wewnątrztekstowe, charakteryzują jednocześnie samego mówiącego.

Z definicji słownikowych przymiotnika regularny wynika, że głównym komponentem semantycznym jednostki jest powtarzalność w c zasie te g o, o czym komunikuje predykat konstytuujący zdanie. Trudno nie zgodzić się z intuicją leksykografów. Na czym polega jednak ta powtarzalność i co jej podlega? Przyjrzyjmy się następującym wypowiedzeniom:

(12) Nie poddając się regularnym badaniom oczu, skazujesz się na ślepotę.

(13) Nowy szef wprowadził zwyczaj regularnych cotygodniowych posiedzeń.

(14) Wsłuchiwał się w jego regularny oddech.

Przymiotnik regularny jest atrybutem tylko takich rzeczowników, które nazywają czynności lub procesy, a więc zawierających pojęcie zmiany ('dziania się'), por. np.: regularne badania lekarskie, regularne zjawisko atmosferyczne, regularne positki, regularne jedzenie, regularny seks $(\rightarrow$ regularne uprawianie seksu), regularna gimnastyka $(\rightarrow$ regularne uprawianie gimnastyki), regularny wysitek, regularny trening, regularny zabieg, regularne picie, regularne płacenie (rachunków), regularne odwiedziny, regularny serwis.

Przysłówek regularnie nie może wchodzić w związki składniowo-semantyczne z czasownikami relacyjnymi czy duratywnymi (por. Cyra 1998b). Jest to konsekwencja związku przysłówka (przymiotnika) z pojęciem zmiany. Brak tego pojęcia w podanych niżej przykładach:

(15) *Zosia jest regularnie podobna do matki.

(16) *Regularnie mieszkał w Rzymie.

(17) *Regularnie uwielbiał Presleya. 
Próby parafrazy przymiotnika regularny w bezpośrednim kontekście rzeczownikowym pokazują, że jest on semantycznie derywowany od przysłówka regularnie (por. Grzegorczykowa 1975, Bogusławski 2005, Grochowski 2008b, Maryn 2008), por. np.

regularne badania lekarskie to takie badanie, które robi się regularnie;

regularne zjawisko atmosferyczne to takie zjawisko, które występuje regularnie;

regularna gimnastyka to taka gimnastyka, którą uprawia się regularnie; regularne odwiedziny to takie odwiedziny, które odbywają się regularnie;

regularny ból głowy to taki ból, który pojawia się regularnie (głowa regularnie boli). Nieakceptowalność połączeń tego przymiotnika z rzeczownikami nazywającymi przedmioty potwierdza, że jest on wtórny względem przysłówka. Rzeczowniki nazywające przedmioty łączą się z przymiotnikiem regularny tylko wtedy, jeśli odnoszą się do obiektów, które mogą być charakteryzowane jako powodujące zmiany lub podlegające zmianom. Nie można zatem uznać za poprawne połączeń *regularna ksiażka, *regularne drzewo. Dziwić mogą również konteksty, w których przymiotnik regular$n y$ jest przykładany do nazw osób, por.: ?regularny czlowiek / mężczyzna / dziennikarz (przy założeniu, że to przymiotnik jest pod akcentem). W SJPD pojawia się, co prawda, definicja sugerująca odniesienie przymiotnika regularny również do osób, por.: 'taki, który żyje według ustalonego planu, pilnujący się oznaczonego czasu, dokładny, punktualny: [...] Pan Konopacki jest znany jako czlowiek pracowity i regularny', ale została ona opatrzona kwalifikatorem przestarzałe.

1.3. Przysłówek regularnie, orzekany o zdarzeniu, komunikuje o jego powtarzaniu się w pewnych odstępach czasu (według ISJP 'Jeśli jakieś zjawisko lub jakaś sytuacja powtórzyły się, to wystąiły po raz kolejny'). Za pomocą regularnie wyrażamy krotność predykatu, krotność, która nie jest sprecyzowana liczbowo, jest natomiast zależna od jednostek czasu. Regularnie komunikuje bowiem miarę odstępów czasu, w jakich zachodzi zdarzenie. Odstępy w czasie nie muszą być określone explicite. Warunkiem użycia przysłówka regularnie jest to, by długość odcinków czasu dzielących zdarzenia była względnie równa. Nie da się odnieść przysłówka regularnie do następującego działania: ktoś prowadzi zapiski w pamiętniku, z początku notuje coś raz w tygodniu, następnie dwa razy w miesiącu, kolejne notatki 
zamieszcza co kilka miesięcy, by potem znów wrócić do zapisków cotygodniowych. Oczywiście o pierwszym okresie prowadzenia pamiętnika można powiedzieć 'prowadził pamiętnik regularnie', ten sam predykat może być przypisany ostatniemu okresowi. Nie sposób orzec jednak regularnie o całym okresie prowadzenia notatek, por. wypowiedzenie (5).

1.4. Przysłówek regularnie komunikuje o nieaktualności zdarzenia nazywanego przez predykat konstytuujący zdanie. Nieaktualność jest konsekwencją powtarzalności, np.:

(18) Podlewam kwiaty w ogrodzie.

(19) Regularnie podlewam kwiaty w ogrodzie.

Regularnie w znaczeniu przedmiotowym może być dodawane tylko do czasowników niedokonanych, por. zdania (4)-(6) i (19) z nieakceptowanymi:

(20) *Regularnie odwiedziliśmy przyjaciół w Krakowie.

(21) *Mama regularnie upiekła ciasto drożdżowe.

(22) *Regularnie zrobiłam porządki w całym domu.

Komponent semantyczny zdający sprawę z cykliczności zdarzeń może zostać osłabiony w wyniku odniesienia do badanego przysłówka operatorów gradacji, takich jak np. dość, w miarę, niezbyt, por. np.:

(23) Otrzymywała emeryturę dość regularnie.

(24) Odkąd znów zaczęłam w miarę regularnie biegać, czuję się lepiej i zrzuciłam trzy kilogramy.

(25) Anna niezbyt regularnie korzysta z usług kosmetyczki.

1.5. Przysłówek regularnie może współwystępować z określeniami komunikującymi o czasie dzielącym powtarzające się czynności (zdarzenia), o mierze odstępów czasu. Odległość czasowa między powtarzającymi się zdarzeniami może być wyrażona explicite za pomocą wykładników leksykalnych. Określają one dokładnie, z jaką częstością powtarzają się zdarzenia, o których mowa w zdaniach, por. np.:

(26) Emeryturę otrzymuje regularnie co miesiąc.

'co miesiąc - w odstępach wyznaczonych przez konwencjonalnie przyjętą jednostkę miary czasu, jaką jest miesiąc'

(27) Regularnie co roku odbywają się na tej scenie wspaniałe koncerty. 
(28) Wymykał się z domu regularnie co noc.

(29) Regularnie co sobota wieczorem wychodzę do znajomych.

'co sobota - w punktach czasowych o konwencjonalnie przyjętej nazwie - sobota'

(30) Chodził do kościoła bardzo regularnie - w każdą niedzielę.

(31) Regularnie każdego ranka zażywała gimnastyki na świeżym powietrzu.

Grupa imienna o postaci: przyimek co + rzeczownik temporalny, np. co dzień, co niedziele (niedziela), co noc, wprowadza informację o regularnym powtarzaniu się zdarzenia i jego częstości. Wyrażenia typu w każdq niedzielę, każdej niedzieli reprezentują połączenia jednostek o postaci $c o \mathrm{~N}_{\mathrm{n} / \mathrm{g} / \mathrm{a}}$. Jednostka każdego $N$ komunikuje o współwystępowaniu zdarzenia z miarą czasu (punktem lub odcinkiem czasu) (por. Cyra 1998a). Wstawienie przysłówka regularnie do zdań, w których obok konstrukcji co $\mathrm{N}_{\mathrm{n} / \mathrm{g} / \mathrm{a}}$ występuje jednostka neutralizująca informację o cykliczności zdarzeń, wprowadzoną przez grupę imienną co $\mathrm{N}_{\mathrm{n} / \mathrm{g} / \mathrm{a}}$, powoduje dewiacyjność zdania pod warunkiem, że nie zrealizuje się pauzy (sygnalizowanej przecinkiem) po regularnie:

(32) *Regularnie, mniej więcej co trzy dni odwiedzał matkę 2

(33) *Regularnie, prawie co noc powracał nad rankiem i wpadał w bramę z hałasem.

Por. w pełni akceptowalne:

(34) Regularnie, a mianowicie mniej więcej co trzy dni odwiedzał matkę.

Przysłówek regularnie może współwystępować również z ciągami typu co krok, co kilometr, co stacja, co przystanek. Takie połączenia niosą informację o stałym współwystępowaniu zdarzenia z jednostką czasu. Czas wyznacza się jednak poprzez odesłanie do punktów w przestrzeni lub do przebytej odległości przestrzennej (zob. Cyra 1998b). Por. np.:

(35) Koń regularnie co przystanek dostawał swoją porcję owsa.

(36) Regularnie co stacja informowano podróżnych o dalszej trasie podróży.

2 Przykłady pochodzą z artykułu Krystyny Cyry (Cyra 1998b). 
W obu przytoczonych zdaniach mówi się o współwystępowaniu zdarzeń opartym na powtarzalności. Istota rzeczy polega na tym, że ilekroć pojawia się pierwsze zdarzenie (w zdaniu (35) jest to przystanek), pojawia się także i drugie (w zdaniu (35) jest to podanie owsa koniowi). Po jakimś czasie powtarza się taka para zdarzeń (zdarzenie pierwsze i współwystępujące z nim zdarzenie drugie). Między jedną a drugą parą tego samego rodzaju istnieje analogia. Długość odcinka czasu, jaki upływa między zdarzeniami, nie jest w tym wypadku relewantna.

Głównym komponentem struktury semantycznej przysłówka regularnie powinna być więc informacja o wielokrotnym współwystępowaniu pary zdarzeń. Informacja o mierze odstępów czasu, w jakich powtarza się współwystępowanie zdarzeń (pojawia się para zdarzeń), jest informacją drugorzędną, wynikającą z kontekstu.

Zależność polegającą na współwystępowaniu pary zdarzeń można wyrazić za pomocą następującej formuły:

\section{$\ulcorner(p \cap\ulcorner q) ;\ulcorner(p \cap\ulcorner q)$ więcej niż raz,}

gdzie $\mathbf{p}$ to zdarzenie, które ma miejsce wtedy, gdy zachodzi $\mathbf{q}$ - drugie zdarzenie, q może stanowić jedynie koniec odcinka czasowego dzielącego $\mathbf{p}, \mathbf{p}_{1},(\ldots), \mathbf{p}_{\mathbf{n}}$, może być punktem na osi czasu.

Wykładniki miary czasu uszczegóławiające znaczenie przysłówka regularnie występują w postpozycji wobec przysłówka, jeśli między przysłówkiem a tym wykładnikiem nie ma pauzy. Dopuszczalna jest antepozycja określnika, jeśli między określnikiem a przysłówkiem wystąpi pauza; por. np.

(37) Co miesiąc_regularnie dostaje emeryturę.

1.6. Skoro głównym komponentem struktury semantycznej przysłówka regularnie jest współwystępowanie pary zdarzeń (zdarzenie występuje po raz kolejny na osi czasu), uzasadnione wydaje się pytanie, czy wystarczy, by coś zdarzyło się jeszcze raz, aby można było orzec, że dzieje się regularnie. Jak stwierdził Maciej Grochowski, „stany rzeczy określane jako kolejne są [...] elementami pewnego ciągu i występują $\mathrm{w}$ tym ciągu po innych, należących do niego elementach" (Grochowski 2003:199). Zgodnie z ustaleniami Grochowskiego, kolejność opiera się na wyliczaniu elementów, opera- 
cji niezamkniętej. „Aby jednak w ogóle mogła mieć ona miejsce, trzeba podać co najmniej trzy elementy. Mniejsza ich liczba nie może konstytuować szeregu (por. Bednarek 2001) jako rezultatu operacji wyliczania" (Grochowski 2003: 201).

Podobne zależności dotyczą badanego przysłówka. Nie sposób powiedzieć, że coś dzieje się regularnie, jeśli miało miejsce zaledwie dwa razy, por. np.:

(38) *Małgosia w ubiegłym roku regularnie korzystała z solarium - była w solarium dwa razy.

Zdanie to może być interpretowane jako poprawne, ale tylko wtedy, gdy opatrzymy je dodatkowym komentarzem

(39) Małgosia w ubiegłym roku regularnie korzystała z solarium - była w solarium dwa razy, a musisz wiedzieć, że Małgosia co roku korzysta z solarium dwa razy. [Małgosia co roku dwa razy chodzi do solarium i robi to od $n$ lat - para współwystępujących zdarzeń: kolejny rok - dwukrotne skorzystanie $\mathrm{z}$ solarium]

Jeśli Małgosia przez $n$ lat raz do roku korzysta z solarium, to również można mówić o regularności. Twierdzenie o cykliczności zdarzeń (powtarzającej się parze zdarzeń) jest uzasadnione i w tym wypadku.

1.7. Przyjrzyjmy się teraz dokładniej wypowiedzeniom

(40) Aleksy II regularnie odmawia spotkania z papieżem.

(41) Janek regularnie nie odrabia lekcji.

(42) Małgosia regularnie spóźnia się na umówione spotkania. [spóźnia się $\approx$ nie jest o czasie]

We wszystkich przytoczonych kontekstach mówi się o powtarzalności zdarzeń. Nie mówi się jednak nic o długości odcinka czasu dzielącego poszczególne zdarzenia, a jedynie o tym, że zdarzenie, o którym komunikuje predykat konstytuujący zdanie, powtarza się, występuje za każdym razem, gdy ma miejsce pewna sytuacja. Jak stwierdziła Krystyna Cyra (1998a: 117), „leksem za każdym razem charakteryzuje zdarzenie pod względem ilościowym (mówi o tym, ile razy miało ono miejsce), nie przypisuje mu jednak określonej wartości liczbowej, ale odnosząc się do innego zdarzenia (czy do 
odcinka czasu), wskazuje na równoliczność obu zdarzeń". Za każdym razem niesie ponadto informację o powtarzalności zdarzeń.

Zdania (40)-(42) można zatem interpretować w następujący sposób 'dla każdej takiej sytuacji, że Aleksy II ma spotkać się z papieżem, charakterystyczne jest to, że odmawia spotkania'; 'dla każdej takiej sytuacji, że Janek ma odrobić lekcje, charakterystyczne jest to, że ich nie odrabia', 'dla każdej takiej sytuacji, że Małgosia ma umówione spotkanie, charakterystyczne jest to, że się na nie spóźnia'.

Konteksty (40)-(42) mogą sugerować, że znaczenie bezwzględnej powtarzalności zdarzeń komunikowane jest jedynie wówczas, gdy w strukturę semantyczną nazwy zdarzenia wpisane jest pojęcie negacji. Przeczy temu jednak niedewiacyjne zdanie

(43) Janek podczas choroby regularnie pije tran.,

które można interpretować w podobny sposób 'dla każdej takiej sytuacji, że Janek jest chory, charakterystyczne jest to, że pije tran'. Możliwa jest również $\mathrm{i}$ inna interpretacja: 'dla sytuacji, gdy Janek jest chory, charakterystyczne jest to, że pije tran w regularnych odstępach czasu'. Powtarzalność nie dotyczy wówczas całej sytuacji choroby i powiązanej z nią sytuacji picia tranu. To picie tranu powtarza się w regularnych odstępach czasu podczas jednej choroby Janka.

2. Regularność sprowadzająca się do powtarzalności zdarzeń jest cechą tego, co uporządkowane, a więc nie jest nieprzewidywalne. Dotyczy pewnego porządku świata, porządku stanów rzeczy. Porządek oparty na powtarzalności zdarzeń to porządek, który można sprowadzić do braku odstępstw od pewnego wzorca. Regularność jest zadana wobec pewnego wzorca, którego należy się domyślać. Nie dziwi więc fakt, że jest ona inherentną cechą gramatyki, która jest niczym innym, jak zbiorem reguł językowych.

Rzeczywistość jest nam dana jedynie w postaci słownej. Reguły rządzące tą rzeczywistością są więc de facto regułami językowymi (zob. Bogusławski 2009).

Nie jest więc przypadkiem fakt, że określenie regularny odnosimy bardzo często do zjawisk przyrody, por.:

(44) Deszcz pada regularnie. 
Deszcz, który pada w regularnych odstępach czasu, spełnia istniejący w świadomości mówiącego wzorzec. Odstępstwo od tego wzorca powoduje, że postrzegamy to zjawisko jako nieregularne.

Wydaje się, że o powtarzalności mówi się również w połączeniach typu: regularne ksztatty, regularny prostopadtościan, a także w zdaniach:

(45) W jego obrębie włókna kolagenowe układają się mniej regularnie.

(46) Regularny kontur katedry odbija się w wodzie regularnym łukiem.

(47) Dziedziniec miał kształt niezbyt regularnego czworoboku.

Regularne ksztalty to kształty typowe (dla kształtów tego rodzaju), czyli takie, które widzi się często i poprzez fakt, że są często spotykane, że obserwator często styka się z kształtami tego rodzaju, są oceniane w taki sposób. Jeśli coś jest typowe, to jest takie, że się powtarza, większości obiektom danego rodzaju przysługują dane cechy. Coś, co postrzegane jest przez nas jako regularne, jest postrzegane w ten sposób bez żadnych zastrzeżeń (i właśnie ze względu na swoją typowość, powtarzalność dany obiekt nie zwraca naszej uwagi) (Bogusławski 1975).

ISJP podaje następującą definicję interesującej nas jednostki: 'Regularne formy, figur i kształty odznaczają się symetrią, powtarzalnością lub podobieństwem albo podobne są do figur geometrycznych'. Choć użyte w definicji pojęcie symetrii można sprowadzić do p o w t a r z a l n o ś c i pewnych punktów w przestrzeni, uzasadnione wydaje wyodrębnienie tego typu kontekstów ${ }^{3}$.

2.1. Dokładniejszy opis jednostek regularny i regularnie będzie możliwy dopiero wtedy, gdy dokona się porównania obydwu ciągów z przymiotnikami i przysłówkami semantycznie spokrewnionymi.

Przymiotnik regularny w większości słowników języka polskiego, w części swych użyć, jest utożsamiany z takimi ciągami jak miarowy i równomierny. Ciągi te nie są jednak tożsame semantycznie z rozpatrywanym tu przymiotnikiem, a na pewno nie mogą być bezwzględnie wzajemnie substy-

3 Warto zwrócić również uwagę na specyficzne użycie jednostki regular w języku angielskim:

(1) He is a regular doctor, not a specialist.

(2) I take a regular coffee, not an espresso.

Próbując przełożyć przytoczone zdania na język polski, w miejscu przymiotnika regular użylibyśmy zapewne polskiego przymiotnika zwykty / zwyczajny. 
tuowane. Przymiotnik miarowy używany jest przede wszystkim w odniesieniu do dźwięku lub ruchu. Podczas gdy akceptowalne są zdania

(48) Wsłuchiwał się w jego miarowy oddech. / Oddychał miarowo.

(49) Miarowy stukot kół uśpił dziewczynę.

(50) Zza okna dochodził chrzęst żwiru pod czyimiś wolnymi, miarowymi krokami.

i możliwe jest użycie w miejscu przymiotnika miarowy jednostki regularny (ma to naturalnie swoje konsekwencje semantyczne), nie można takiej substytucji dokonać w wypowiedzeniach (1)-(3).

Ograniczenia nałożone są również na dystrybucję jednostki równomierny.

ISJP podaje następującą definicję tego ciągu: Równomierne jest to, co jest równo rozłożone w czasie lub przestrzeni, np. występuje w jednakowych odstępach lub z jednakowym natężeniem, np.:

(51) Churchill mawiał, że socjalizm gwarantuje ludziom równomierny podział niedostatku.

(52) Równomierne przerzedzenie włosów na całej głowie zdarza się i kobietom.

(53) Chyba spał, bo słychać było jego równomierny oddech.

Próba zastąpienia w powyższych wypowiedzeniach przymiotnika równomierny przymiotnikiem regularny musi prowadzić do uznania nowych wypowiedzeń za nieakceptowalne. Substytucja jest natomiast możliwa w wypowiedzeniach:

(54) Wsłuchiwał się w jego równomierny / regularny oddech.

(55) Zaniepokoił go nierównomierny / nieregularny rytm serca.

(56) Serce biło mu równomiernie / regularnie.

Nie są one jednak równoznaczne.

2.2. Przysłówek regularnie charakteryzuje się dość swobodnym szykiem. Zmiana pozycji linearnej badanej jednostki nie pociąga za sobą zmiany znaczenia wypowiedzenia. Regularnie pojawia się zatem zarówno w antepozycji, jak i w postpozycji wobec czasownika. Nie musi występować w jego bezpośrednim kontekście. Zawsze wchodzi jednak w relację syntaktyczną $\mathrm{z}$ czasownikiem. Analiza szyku wymaga powiązania z właściwościami pro- 
zodycznymi wypowiedzenia i STR, co nie należy do przedmiotu tego artykułu. Por.:

(57) Uczył się angielskiego regularnie.

(58) Regularnie przychodził na zajęcia.

(59) Małgosia sprząta regularnie w łazience.

3. Operatory metatekstowe regularny i regularnie występują w kontekstach (7)-(11). Leksemy regularny2 i regularnie2 można uznać za rematyzatory zdań, stanowią komentarz do całości tego, o czym się mówi w zdaniu, a nie do treści poszczególnych elementów wypowiedzenia [stanowią komentarz do rematu] (por. Wajszczuk 2005, Grochowski 2007). Metaoperatory regularny i regularnie otwierają prawostronnie pozycję nacechowaną gramatycznie - dla rzeczownika.

Regularny2 i regularnie2 pełnią zatem w strukturze informacyjnej wypowiedzenia funkcję komentarza przyrematycznego, na co wskazuje miejsce akcentu zdaniowego, por.:

(60) Z Andrzeja to regularny tchó/rz.

(61) To dziecko regularnie kła/mie!

W celu odróżnienia homonimii jednostek reprezentujących klasę przysłówków i przymiotników oraz klasę operatorów metatekstowych stosuję testy zaproponowane przez Magdalenę Danielewiczową, w jej tekście Przymiotniki nieprzymiotniki. O pewnym niezwyktym typie wyrażeń $w$ języku polskim (Danielewiczowa 2007).

Funkcją metaoperatorów regularny i regularnie jest obok charakterystyki odpowiedniej klasy obiektów, charakterystyka nadawcy. Polega ona na ukazaniu stosunku nadawcy „,do adekwatności użycia określonego predykatu w odniesieniu do danego przedmiotu wypowiedzi”" (por. Danielewiczowa 2007: 230).

Mówiąc To jest wariat regularny!, mówimy zatem nie tylko o wyrażeniu wariat, ale i o naszym stosunku do obiektu. Wyrażenie regularny2 wnosi do wypowiedzi komponent oceny. Za pomocą tej jednostki mówiący wyraża subiektywne przekonanie, że zachodzi dany stan rzeczy, a nawet więcej - wyraża pewność, że przypisywana właściwość przysługuje danemu obiektowi. Ocena jest również wpisana $\mathrm{w}$ znaczenie przymiotnika $\mathrm{z}$ przedmiotowego 
poziomu wypowiedzi. Chodzi tu jednak tylko o charakterystykę danego stanu rzeczy, wymagającego pojęcia zmiany, a nie o charakterystykę mówiącego, jego stosunek do treści wypowiedzi.

Mówiąc regularny X (regularny2), nie mówię, że X dzieje się regularnie (regularnie1). Chcę raczej znaleźć najwłaściwsze słowo, odpowiedni predykat, który oddaje dany stan rzeczy. Mówiąc $Z$ Andrzeja to regularny tch/órz, komunikuję zatem, że tchórz to najwłaściwsza nazwa na stan rzeczy, który opisuję, a który nie jest obiektywny.

4. Hipotezę o homonimii jednostek o postaci regularny i regularnie potwierdza wiele faktów językowych.

Metaoperator regularny2, jako jednostka nie mająca odniesienia przedmiotowego, charakteryzuje się apredykatywnością, por. np.:

(62) Zaparzyłeś mi regularną lurę!

(63) *Lura, którą mi zaparzyłeś jest regularna.

(64) Z Andrzeja to regularny wariat.

(65) *Wariat, jakim jest Andrzej, jest regularny.

Tylko regularnyl może pojawić się w pozycji orzecznikowej, por. np.:

(66) By masaż dał jakieś efekty, powinien być przede wszystkim regularny.

(67) Ich spotkania były zawsze regularne.

Apredykatywność jednostki regularny2 i regularnie2 pociąga za sobą jej arematyczność (metaoperatory nie mogą być użyte rematycznie). Operator metatekstowy nie przyjmuje na siebie niekontrastywnego akcentu zdaniowego (por. Bogusławski 1977, Danielewiczowa 2007). Podobnie zachowują się badane metaoperatory. Wyrażenia z przedmiotowego poziomu języka moga być użyte rematycznie, co potwierdza procedura kontrastowania eliminacyjnego. Możliwe jest zaakcentowanie przysłówka (lub przymiotnika), por. np.:

(68) Kwiaty w ogrodzie powinny być podlewane regul/arnie, a nie od czasu do czasu.

(69) Książki należy czytać regul/arnie, a nie od święta! 
Przysłówek regularnie, w opozycji do homonimicznego z nim meta operatora, jest transformowalny na grupę nominalną przyimkową zawierającą przymiotnik, np.

(70) Emeryturę otrzymuje regularnie (w regularnych odstępach czasu).

(71) W jego obrębie włókna kolagenowe układają się regularnie / w sposób regularny (w regularnych odstępach przestrzeni).

Przymiotnik i przysłówek może wchodzić w relacje z operatorami gradacji. Podobne związki wykluczają operatory metatekstowe, np.:

(72) Rzadko bywam w kraju, mało regularnie i na dodatek zawsze na krótko.

(73) Spotykał się z nią dość regularnie.

(74) Tylko bardzo regularny trening może dać spektakularne efekty.

(75) Odkąd znów zacząłem w miarę regularne spacery, zrzuciłem trzy kilogramy.

(76) *On bardzo regularnie kłamie!

(77) *To bardzo regularny wariat!

Jednostki przedmiotowe, zarówno przysłówki, jak i przymiotniki, mogą kookurować (lub łączyć za pomocą koniunkcji) z innymi jednostkami przedmiotowymi. Operacja taka jest niemożliwa w wypadku jednostek metatekstowych, w tym także interesujących mnie metaoperatorów, np.

(78) Prowadził ustabilizowany, regularny tryb życia.

(79) Organizował regularne cotygodniowe posiedzenia.

(80) *To regularny, wielki nudziarz!

Kolejny dowód na istnienie jednostek homonimicznych o kształcie regularny stanowi fakt, że regularny2, w odróżnieniu od przymiotników mających znaczenie przedmiotowe, nie może pełnić wraz z rzeczownikami funkcji referencjalnej; por.

(81) Lubię gimnastykę. Jaką? Regularną.

(82) To wariat! Jaki? *Regularny!

Jednostki regularny i regularnie z przedmiotowego poziomu języka są niestopniowalne. Jednostki metatekstowe (zarówno regularny2, jak i regu- 
larnie2) nie mają form komparatiwu, możliwa jest natomiast forma superlatiwu, również jako część wielosegmentowego metaoperatora $\mathrm{z}$ elementem w świecie. Ciągi o takiej postaci funkcjonują zwłaszcza w wypowiedziach języka potocznego (Danielewiczowa 2009, Grochowski 2008a); np.:

(83) On najregularniej [w świecie] kretynieje!

Oba znaczenia różni ponadto stosunek do negacji. Nie ma możliwości odniesienia metapredykatu nieprawda, a także partykuły nie do metaoperatora w sposób inny niż cytacyjny. Regularny o znaczeniu przedmiotowym może być zanegowane bez żadnych zastrzeżeń, por. np.:

(84) Regularnie ćwiczę palcówki na pianinie.

(85) Nieprawda, że ćwiczę palcówki na pianinie regularnie.

Koronnym argumentem za istnieniem dwóch leksemów o kształcie regularny / regularnie jest możliwość ich współwystępowania w jednym wypowiedzeniu, por.

(86) Piotr regularnie regularnie kłamie.

4.1. Nie ulega wątpliwości ograniczona łączliwość metaoperatorów regularny i regularnie. Przegląd kontekstów, w których pojawiają się operatory regularny2 i regularnie2, pozwala na wysnucie wniosków, że badane ciągi występują najczęściej w sąsiedztwie jednostek określających kogoś, kto jest wyznawcą pewnej postawy, która jest przez nas odrzucana, która jesteśmy skłonni oceniać negatywnie (bądź kogoś, kto postępuje w sposób niewłaściwy). Takie ograniczenie nie jest jednak motywowane semantycznie, lecz czysto pragmatycznie, por. np.:

(87) Z Marka to regularny k/ołtun, marks/ista.

(88) Anna to regularna d/ulska, dew/otka.

(89) ? Z Marka to regularny m/urarz / naucz/yciel / podr/óżnik / racjonal/ ista/ ideal/ista.

(90) ? Piotrek to regularny wielb/iciel opery.

Metaoperatory regularny / regularnie mogą być użyte w zdaniach hipotetycznych, znoszących asercję, w wypowiedzeniach, w których przedmiotem informacji nie jest obiektywny stan rzeczy, ale stan przekonania nadawcy 
o prawdziwości tego, o czym mówi, stan inny niż pewność. Możliwe jest zatem użycie metaoperatorów w zdaniach, w których informacja o ustosunkowaniu się nadawcy względem komunikowanego zdarzenia jest przedmiotem asercji, przekazywana jest w sposób eksplicytny, za pomocą czasowników epistemicznych typu: przypuszczam, że_, wydaje mi się, $\dot{z} e_{-}$, por. np.:

(91) A. Dlaczego nie przychodzi? B. Przypuszczam, że regularnie stchórzył.

(92) Coś mi się wydaje, że ty regularnie kłamiesz.

Niesprzeczność zdań (91) i (92) wynika najprawdopodobniej z faktu, że oba predykaty propozycjonalne zawierają w swojej strukturze semantycznej komponent zdający sprawę z gotowości $a$ do powiedzenia $p$, w wyniku braku danych negatywnych, które powodowałyby to, że $a$ nie byłby gotów powiedzieć, że $p$ zachodzi (por. Danielewiczowa 2002). Nie jest wykluczone wystąpienie badanych operatorów w zdaniach z referencją nieokreśloną, np.:

(93) Jakiś/pewien w/ariat regularny pytał wczoraj o ciebie.

(94) Jakiś/pewien regularny w/ariat zaczepia mnie codziennie w metrze.

Zdania (93) i (94) odnoszą się do jednostkowego obiektu, który nie jest przez nadawce jednoznacznie scharakteryzowany. Fakt ten nie stoi jednak w sprzeczności z możliwością orzekania o obiekcie predykatu wariat, a nawet więcej, nie wyklucza pewności nadawcy co do adekwatności użycia wspomnianego predykatu, o czym komunikuje operator regularny.

Metaoperator regularny jest wtórny wobec operatora metatekstowego regularnie. Postawioną tezę potwierdzają następujące przekształcenia:

(95) On regularnie r/obi z siebie wariata. $\rightarrow$ To w/ariat regularny.

(96) On regularnie kł/amie. $\rightarrow$ To kł/amca regularny.

(97) On regularnie kr/adnie. $\rightarrow$ To regularny zł/odziej.

W świetle postawionych hipotez proponuję następującą formułę interpretacyjną dla metaoperatora regularny (regularnie). Proponowana definicja ma charakter hiperonimiczny i wymaga weryfikacji po przeprowadzeniu dalszych stosownych badań (por. Wajszczuk 2005: 134):

'ten ktoś (to coś) - wiesz o kim (o czym) mówię - jest taki(e), że muszę o nim (o tym) pod pewnym względem, istotnym ze względu na to, o czym mowa, powiedzieć coś (y)' 
4.2. Interesujące wnioski przynosi porównanie znaczenia metaoperatorów regularny i regularnie z operatorami metatekstowymi zwykty i zwyczajny, a także normalny i normalnie (por. Maryn 2008, 2009a, 2009b). Frekwencja tekstowa (liczba wystąpień w korpusie PWN) metaoperatorów regularnie i regularny jest bardzo niska, w porównaniu z jednostkami zwykły / zwyczajny czy normalny / normalnie o znaczeniu metatekstowym. Sa to jednak wyrażenia wyspecjalizowane w pełnieniu tej samej funkcji w wypowiedzeniu, stanowią komentarz przyrematyczny. Funkcjonują przede wszystkim w wypowiedziach języka potocznego. Dopuszczalna jest ich wzajemna substytucja.

5. Przymiotnik regularny jest elementem zestawień funkcjonujących jako wyrażenia zleksykalizowane. Porównaj np. wypowiedzenia:

(98) Regularne linie lotnicze obsługują pasażerów na wielu trasach.

(99) Wokół oddziału partyzanckiego rozłożyły się regularne oddziały, bitny i ostrzelany żołnierz frontowy.

(100) Po jednej stronie była regularna armia, po drugiej terroryści.

(101) Rozpoczęła się regularna wojna, z udziałem prowincjonalnej milicji.

(102) Uczyła się na pamięć czasowników nieregularnych.

Wszystkie ważniejsze słowniki języka polskiego notują przedstawione użycia badanych jednostek i przypisują im odrębne definicje. Oddzielne definicje przypisano również ciagom regularny gość i regularny tryb życia. Wbrew opisom słownikowym należałoby uznać je za połączenia przymiotnika regularny z odpowiednimi rzeczownikami, por. np. konteksty:

(103) Niektórzy artyści stali się regularnymi gośćmi w Zamku.

(104) Prowadził regularny tryb życia.

Wydaje się, że we wszystkich wyróżnionych użyciach można dopatrzeć się wspólnego komponentu semantycznego komunikującego o pewnej powtarzalności, cykliczności dziania się, o współwystępowaniu pary zdarzeń (co jakiś czas zdarzenie się powtarza).

6. Przytoczone argumenty potwierdzają postawioną przeze mnie teze o istnieniu homonimów o kształcie regularny / regularnie reprezentujących klasę przymiotników i przysłówków, a także operatorów metatekstowych. 
Przedstawione obserwacje stanowiąjedynie wstęp do dalszego, systematycznego opisu, który w konsekwencji ma doprowadzić do zbudowania formuł eksplikacyjnych badanych jednostek. Nieodzowne wydaje się porównanie opisywanych ciągów z innymi jednostkami, w których znaczenie wpisane jest przypuszczalnie, powszechnie używane pojęcie normy, a więc z wyrażeniami takimi, jak przeciętny, średni, zwykty, zwyczajny, odpowiedni.

\section{Bibliografia}

BednareK A., 2001, Kilka nieuporządkowanych uwag o porządku, w: V. S. Chrakovskij, M. Grochowski, G. Hentschel (red.), Studies on the Syntax and Semantics of Slavonic Languages, Oldenburg: Bibliotheks- und Informationssystem der Universität Oldenburg, s. 31-38.

BogusŁaWski A., 1975, Measures are measures. In defence of the diversity of comparatives and positives, Linguistische Berichte 36, s. 1-9.

BogusŁawski A., 1977, On the Thematic-Rhematic Structure of Sentences, Warszawa: PWN.

Bogusıawski A., 2005, O operacjach przysłówkowych, w: M. Grochowski (red.) Przystówki i przyimki. Studia ze składni i semantyki języka polskiego, Toruń: Wydawnictwo UMK, s. 15-44.

BogusŁawski A., 2009, Myśli o gwiazdce i o regule, Warszawa: Bel Studio.

CYRA K., 1998a: Jednostka leksykalna za każdym razem - próba analizy składniowej i semantycznej, Polonica XIX, s. 113-124.

Cyra K., 1998b: Warunki ekwiwalencji wybranych wykładników regularnego współwystępowania faktów, Poradnik Językowy, z. 10, s. 15-25.

Danielewiczowa M., 2002, Wiedza i niewiedza. Studium polskich czasowników epistemicznych, Warszawa: Katedra Lingwistyki Formalnej UW.

Danielewiczowa M., 2006, Cała ta leksykografia, Kwartalnik Pedagogiczny, nr 4 (202), s. 57-73.

Danielewiczowa M., 2007, Przymiotniki nieprzymiotniki. O pewnym niezwykłym typie wyrażeń w języku polskim, Зборник Матиие српске за славистику 71-72 , Нови сад, s. 223-234.

Danielewiczowa M., 2008, Jak nie należy opisywać przysłówków epistemicznych, Wiener Slawistischer Almanach, Sonderband 72, s. 109-128.

Danielewiczowa M., 2009, Jak używamy słowa spokojnie? Poradnik Językowy, z. 1, s. 29-39. 
Grochowski M., 2003, O znaczeniach przymiotników metatekstowych następny, kolejny, w: M. Gębka-Wolak, I. Kaproń-Charzyńska, M. Urban (red.), Studia z gramatyki i leksykologii języka polskiego, Toruń: Wydawnictwo UMK, s. 196-205.

Grochowski M., 2007, Partykuły, parenteza a wyrażenia metatekstowe, Z polskich studiów slawistycznych, Seria XI. Językoznawstwo, Warszawa, s. 69-74.

Grochowski M., 2008a, Operatory metatekstowe o kształcie superlatiwu przysłówka, Јужнословенски Филолог LXIV, s. 61-72.

Grochowski M., 2008b, O hierarchii kryteriów w opisie przysłówków formalnie odprzymiotnikowych, w: M. Sarnowski, W. Wysoczański (red.), Wyraz i zdanie w językach słowiańskich 6. Opis, konfrontacja, przekład, Wrocław: Wydawnictwo Uniwersytetu Wrocławskiego, s. 121-128.

Grzegorczykowa R., 1975, Funkcje semantyczne i składniowe polskich przystówków, Wrocław: Ossolineum.

ISJP, 2000, Inny słownik języka polskiego, M. Bańko (red.), Warszawa: Wydawnictwo Naukowe PWN.

MARYN D., 2008, O cechach składniowych i semantycznych jednostek przeciętny (przeciętnie) i średni (średnio), w: J. Kamper-Warejko, I. Kaproń-Charzyńska (red.), Z zagadnień leksykologii i leksykografii języków słowiańskich, Toruń: Wydawnictwo Naukowe UMK, s. 267-274.

MARYN D., 2009a, O znaczeniach przedmiotowych i metatekstowych przymiotników zwykły i zwyczajny, w: B. Milewska, S. Rzedzicka (red.), Wokół słów i znaczeń III. Z zagadnień leksykalno-semantycznych, Gdańsk: Wydawnictwo Uniwersytetu Gdańskiego, s. 293-300.

MARYN D., 2009b, O cechach składniowych i semantycznych jednostek normalny i normalnie, (w druku).

SFPW, 1990, Słownik frekwencyjny polszczyzny współczesnej, Z. Saloni (red.), Kraków: Instytut Języka Polskiego PAN.

SJPD, 1958-1969, Słownik języka polskiego, W. Doroszewski (red.), Warszawa: Wiedza Powszechna, PWN.

SJPSz, 1978-1981, Słownik języka polskiego, M. Szymczak (red.), Warszawa: PWN.

SWJP, 1999, Słownik współczesnego języka polskiego, B. Dunaj (red.), Warszawa: Wilga.

USJP, 2003, Uniwersalny słownikjęzyka polskiego, S. Dubisz (red.), Warszawa: Wydawnictwo Naukowe PWN.

Wajszczuk J., 2005, O metatekście, Warszawa: Katedra Lingwistyki Formalnej UW. 


\section{On the syntactic and semantic features of the items regularny (regular) and regularnie (regularly / in a regular way) \\ ( s u m m a r y)}

The purpose of this article is to describe the syntactic and semantic properties of the units regularny and regularnie. The basic thesis concerns the existence of homonyms in the form regularny / regularnie representing the class of adjectives and adverbs as well as metapredicative operators. The adverb regularnie, from which the adjective regularny is semantically derived, conveys the idea of repetitiveness of an event at specific, relatively equal time intervals. The metapredicate regularnie constitutes a comment on the rheme, it confirms the accuracy of use of a particular predicate. 